\title{
COMUNICAÇÃO E MEDIAÇÕES
}

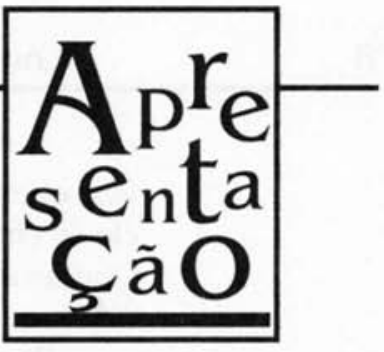

A chamada cultura de massas tem como uma de suas bases o jogo permanente e inacabado. A manifestação mais evidente do jogo pode ser percebida quer na tradicional seção de palavras cruzadas de um jornal quer nos programas de auditório que o rádio consagrou e os canais de televisão continuam a implementar.

Jogar é procurar vencer algumas barreiras interpostas no percurso para que se alcance um determinado objetivo. Essas barreiras constituem a resistência que temos que vencer para obtermos algum prazer.

Também nos noticiários, que se constituem na hora da "realidade", quando se mostra o que está acontecendo "de verdade", o jogo está presente. Sem ele, a dose de entretenimento indispensável à eficácia dos meios se perderia. Também aí tudo se transforma em jogo. Até mesmo a realidade sociopolítica, repleta de dramas e tragédias.

Quem não se lembra do processo de impeachment do ex-presidente Collor e a caçada a Paulo César Farias. A questão sociopolítica central —os desmandos cometidos contra o Estado brasileiro - transformaram-se, à época, no jogo de esconde-esconde entre PC Farias e a Polícia Federal. E todos os brasileiros se colocaram na condição de torcedores, até que, vencidas as barreiras, o jogo foi ganho: prendeu-se PC Farias. Os desmandos, esses ficaram para outra ocasião.

Como se vê, a cultura de massas reduz a questão, particularizando-a; transforma-a em jogo, levando-nos a "torcer" por um determinado resultado; e transforma em espetáculo os acontecimentos.

Ocorre que na realidade "vivida" encontramos muitas resistências, nada artificiais, e que não se manifestam apenas como barreiras virtuais no caminho da vitória. Pelo contrário, as resistências são concretas, não se apresentam somente como obstáculos de um jogo, muitas vezes não têm a condição de espetáculo que encanta. São elas a base da prática social do nosso grupo e da nossa individualidade. A partir dessa base vamos "ler" e "compreender" os meios de comunicação, seja o cinema, o rádio, a televisão, o jornal etc.

Por isso, ao se tratar do papel dos meios de comunicação, é fundamental que, antes de tudo, se possa saber o que resulta do embate entre o jogo que está nos meios e as "jogadas" de quem precisa sobrevi-

\section{A AUTORA \\ Maria Aparecida Baccega \\ Doutora em Letras e Ciências da Comunicação. Professora Associada da Escola de Comunicações e Artes da USP. Especialista em Linguagem Ver- bal nos Meios de Comunicação. Coordenadora do Curso "Gestão de Processos Comunicacionais".}


ver; que uso fazem as pessoas do espetáculo oferecido pelos meios quando ele se choca com o espetáculo das vidas ao seu redor e da sua própria vida? Que uso fazem desses jogos, desses espetáculos, as pessoas que vêem televisão, que assistem ao filme, que lêem o jornal ou ouvem o rádio.

Precisamos ter claro que a significação do "conteúdo" dos meios só se completa no momento em que alguém ouve, lê ou vê. Nesse momento, o receptor agrega ao significado que recebe o significado que sua cultura lhe possibilita depreender. Aí está um dos níveis das mediações.

A identidade do cidadão, do ser brasileiro, está relacionada à "imagem" que os meios de comunicação divulgam. Como é o país onde vivemos, quais os traços, os comportamentos de nosso povo que nos unem uns aos outros? Aqui, são os meios de comunicação que se constituem, eles próprios, como mediações privilegiadas. Este é um outro nível das mediações. São elas que colaboram para a instituição de nossa identidade como indivíduo/sujeito e como cidadão.

Tomando-se as mediações como ponto de partida, o campo da comunicação/ educação abrange, portanto, como parte constitutiva dele e não como exterior a ele todos os processos que participam da dinâmica que instaura a significação: quer no nível sociopolítico-econômico, quer no nível das "transformações" que cada grupo social e cada indivíduo desse grupo realizam, no seu cotidiano, dessas questões nacionais.

Este número da revista Comunicação e Educação preocupou-se em mostrar um pouco até que ponto a identidade de cada um de nós - ponto de apoio para ajudar a construir a significação do que dizem os meios - é marcada pelas mediações, em ambos os níveis.

\section{ARTIGOS NACIONAIS}

Por isso, abrimos os Artigos Nacionais com Cinema Educativo: uma abordagem histórica, de Eduardo Morettin, que vai mostrar o modo que as relações cinema-educação vêm sendo encaradas, desde meados da década de 20. O maniqueísmo, que caracteriza a crítica moral, sempre abriu espaço para a censura. Em 1928, diz o autor, a censura cinematográfica está sob a responsabilidade do Ministério do Interior e da Justiça, "cabendo aos chefes de polícia locais a vigilância pelo bom cumprimento das suas disposições".

Por outro lado, o cinema tem sido o grande aliado no ensino da História, a qual tem grande importância na construção dessa identidade sociopolítico-econômica. Por isso, a "recomposição cinematográfica de uma época" sofreu pesadas críticas ao longo dos anos: sempre no caminho de preservar os "heróis" que interessam ao poder estabelecido. Várias são, portanto, as mediações até que possamos "ler" o filme, dando-lhe significação a partir da nossa identidade.

Mary Enice R. de Mendonça, em seu artigo Breve painel do cinema brasileiro, ressalta a "importância que o cinema tem na elaboração da imagem de seu povo, não apenas para o exterior, mas principalemnte para seu público interno". Fazendo uma síntese da história do cinema brasileiro, ao mesmo tempo em que o inter-relaciona ao cinema latino-americano, este texto chega até o Cinema Novo, movimento que caracterizou a América 
Latina na década de 60 e que propunha a Estética da Fome (famoso manifesto de Gláuber Rocha). O poder ditatorial que se instala no Brasil e em outros países da América Latina, rapidamente destrói esse cinema.

Completando esta abordagem sobre cinema brasileiro, este número traz a entrevista com Carla Camuratti, que fala sobre seu filme Carlota Joaquina. Neste um ano de existência, justamente o ano em que o cinema comemora 100 anos, esta revista publicou: Sobre sedução na arte e na mídia, de Ana Maria Ballogh; Lamarca: um nome para ser lembrado, de Maria Lourdes Motter; Lamarca, o filme, de Mary Enice R. de Mendonça, todos no n* 1; Prazer audiovisual, de Marília Franco, no n²; Pornochanchada: doce sabor da transgressão, de Válter Vicente Sales Filho; Como uma ópera: Conterrâneos velhos de guerra, de Eduardo Leone, no n 3, além da Videografia para o trabalho de professores de primeiro e segundo graus, de Ismar de Oliveira Soares, Antônio Reis Júnior e Maria Inês Carlos Magno, seção permanente da revista. Não é muito, sabemos. Mas nos moveu o desejo de participar com alegria dessa festa do cinema, que é, na verdade, uma festa de todos nós.

A televisão tem se revelado, também, uma fonte de parâmetros para a construção das mediações que usamos para "ler" os meios. Para ler a própria televisão. Então, como devemos agir, pais e professores, educadores em geral, em relação a ela? É o que discute Tânia Maria Esperon Porto, no seu artigo Televisão e escola: escolas paralelas? A televisão, como o cinema, trabalha com imagem, a qual, segundo a autora, "funciona como 'dobradiça' que articula o interior do sujeito, seu imaginário, suas idéias, suas motivações e seus conhecimentos aos elementos do mundo real".

Essa articulação do imaginário está presente no artigo de Alice Vieira Autonomia no jogo da leitura, em que a autora, demonstrando o poder do jogo, trabalha-o no meio de comunicação mais antigo (depois das cordas vocais): a escrita, o livro. Trata-se de uma leitura em forma de jogo, cuja "senha de entrada é o imaginário". Nesse roteiro, "o conhecimento prévio do leitor-jogador ativa-se, colocando em jogo um leque de conhecimentos: lingüístico, textual, do mundo, juntamente com sua capacidade cognitiva." Aí estão presentes, portanto, vários níveis das mediações - o nível macro, onde procuram "conformar", "dar forma" ao nosso imaginário, e o nível individual, onde cada qual, a partir de seu grupo social, vai construir sua própria mediação e emprestar significação à leitura.

Por que, com a presença já indiscutível de todo esse aparato de comunicação/ arte, a escola ainda fala em "promoção cultural" como algo fora do currículo, fora dela mesma? É o que vai discutir Irene Tourinho, em seu artigo Promoção cultural e ensino: alguns desafios. Já não seria hora de as escolas incorporarem as questões dos jogos, das artes, das comunicações como parte delas próprias?

Para agilizar essa incorporação surgem novos atores sociais. Ismar de Oliveira Soares, no artigo Tecnologias da informação e novos atores sociais, vai falar do educomunicador: aquele profissional capaz de fazer interagir os campos da comunicação e da educação, o gestor de processos comunicacionais no espaço do ensino formal e não formal. 
O conhecimento para a adequação do uso das tecnologias em favor dos professores já vem se acumulando. É o que você vai ver no artigo de Vicente Gosciola Videogravação em sala de aula. Diz o autor: "Quem está operando a câmera deve se lembrar, entre outras coisas, que sua leitura é um filtro ou um recorte da realidade, a qual será refiltrada pela câmera e que será refiltrada novamente pelo aparelho de TV, antes de ser lida, refiltrada, várias vezes pelo pesquisador". Novamente, a questão das mediações. O que importa é tê-las presente para que saibamos trabalhá-las adequadamente.

O conhecimento é sempre o caminho mais importante para esse trabalho. Vamos perseguir a informação, de Maria de Fátima G. M. Tálamo et al vai nos mostrar algumas teorias de classificação e o que elas têm representado no acesso de todos ao conhecimento. Como dizem as autoras, "o acesso à informação é sempre realizado através de intermediações". A revista considera que o conhecimento dessas mediações é um passo importante para a democratização da informação.

\section{ARTIGOS INTERNACIONAIS}

Continuamos a tradução do artigo Transmissão Educativa, que consideramos uma contribuição às duas discussões de que a sociedade civil deveria participar mais: o ensino a distância e a televisão a cabo, cuja lei, já aprovada e publicada, possilita à comunidade produzir seus próprios programas. É uma corrida contra o tempo. Gostaríamos, inclusive, de pedir aos leitores que nos escrevessem contando experiências que conhecem ou falando de organizações ou movimentos que pretendem trabalhar com TV a cabo. Chegou a vez do Brasil. Gostaríamos muito de que fosse a vez dos brasileiros. Não deixe de ler As múltiplas estratégias do ensino a distância.

\section{ENTREVISTA}

Não poderia haver melhor homenagem aos Cem Anos do Cinema: a entrevista feita por Roseli Fígaro com Carla Camuratti Cinema e História com humor e criatividade. Nela a cineasta fala de seu filme Carlota Joaquina, êxito de público e de crítica. Fala muito mais. Carla fala de tudo: da necessidade de proteção ao cinema, das relações com a História, das privatizações, da quebra do Estado brasileiro etc. E deixa para nós uma lição: ser cineasta é mesmo ser cidadão do mundo.

\section{CRÍtICA}

O jornal Folha de S. Paulo, de 16 de junho de 1995, à página 1-4, na coluna "Painel", em "Tiroteio", coloca:

"De Delfim Netto (PPR-SP), sobre a crise Brasil- Argentina:

-É o fim do Mercosul. Acordo de cavalheiros só pode haver onde há cavalheiros. De novo, o governo não avaliou as consequiências do que assinou e agora não vai cumprir. Que o digam os petroleiros e os agricultores." 
No dia seguinte, 17 de junho de 1995, na Seção "Frases", à página 2 do mesmo jornal, sob o título "Escreveu não leu", lê-se:

"Acordo de cavalheiros só pode haver onde há cavalheiros. De novo, o governo não avaliou as consequiências do que assinou e agora não vai cumprir." E, embaixo, "Antonio Delfim Netto, deputado federal pelo PPR-SP, sobre as importações de automóveis no Mercosul, ontem na Folha".

Como se vê, desapareceram, milagrosamente, duas citações argumentativas do deputado. Um dos argumentos, o acordo que a Presidência da República havia assinado com os petroleiros.

É sobre esse jogo de ocultamento que fala Adílson Odair Citelli, em seu artigo Palavras de ordem. Professor e pesquisador, Adílson aproveita sua crítica para elaborar uma verdadeira aula sobre o "fazer jornalístico". Usa como exemplo a greve dos petroleiros no Jornal Nacional para mostrar o que não se deve fazer. Segundo os próprios manuais de redação, inclusive.

Só para lembrar: assim se constroem as nossas possibilidades de mediação, de entendimento dos significados.

Mas não vamos supor que o "problema" seja a televisão. Maria Lourdes Motter, em seu artigo Revista semanal perde para TV, compara dois meios de comunicação: a televisão e a revista semanal. Ambas abordam o mesmo assunto: os esquimós. E, contra todas as expectativas (e todos os manuais), a superficialidade fica por conta da revista. O Globo Repórter, nesse caso, ofereceu melhores condições de conhecimento da realidade, tratando o tema com a seriedade que ele merece. Vale a pena ler.

\section{DEPOIMENTO}

Lauro César Muniz é dramaturgo da melhor qualidade. Vem do teatro e começa a escrever telenovela na década de 70 . Quem não se lembra de $\mathbf{O}$ Casarão? Ou, mais recentemente, de Roda de Fogo e Salvador da Pátria, entre muitas outras? Pois é. Ele tem acompanhado cada um de nós, diariamente, por vários períodos de nossas vidas.

Em Nos bastidores da telenovela, Lauro César Muniz fala da história desse produto cultural, da influência da telenovela na sociedade e da sociedade na telenovela, da telenovela como manifestação artística etc. Leitura indispensável.

O outro depoimento é de Maria Amélia de Carvalho. Se você ainda não sabe, é ela a criadora do projeto Bambalalão, da TV Cultura. Dispensa, portanto, apresentações. O sucesso desse programa fala por si. Maria Amélia vem nos contar como se faz Teatro de Bonecos, tanto com vistas ao teatroeducação quanto ao teatro-espetáculo.

Ambos os depoimentos nos ajudam a conhecer o "outro lado", o lado de quem faz os meios.

\section{EXPERIÊNCIA}

Cristiane Fernandes Tavares é professora da primeira série do Primeiro Grau. Segundo ela, "o professor, enquanto mediador da aprendizagem" pre- 
cisa instigar a dúvida e apontar as várias fontes do saber. Ela criou a "Hora da curiosidade", dando espaço a seus alunos para que se colocassem. Nesse verdadeiro jogo, aprender "passa a ser uma sucessão de descobertas".

Já na Escola Pacaembu, em São Paulo, a professora de Língua Portuguesa das $7^{\mathrm{a}} \mathrm{s}$ e $8^{\mathrm{a}} \mathrm{s}$ séries alia-se à bibliotecária para elaborarem e executarem o Projeto Leitura 94. É o que Marly Camargo Vidal (a professora) e Sandra Martins da Rola (a bibliotecária) nos contam no seu texto.

\section{SERVIÇOS}

Entre seus Museus, a Universidade de São Paulo conta com o Museu de Arqueologia e Etnologia. Entre suas atividades, todas abertas ao público, várias são voltadas especificamente para o setor educativo. Vale a pena conhecer o texto Museu de Arqueologia e Etnologia de Sandra Medina. E o Museu também.

Do mesmo modo, o Centro Mário Schenberg, que funciona na Escola de Comunicações e Artes (ECA) da USP tem uma série de atividades que estão à disposição dos que trabalham em educação. Mais ainda: que estão abertas à participação dos educadores. É o que Elza Maria Ajzenberg aborda em Centro Mário Schenberg de Documentação de Pesquisa em Artes.

Também desejando a participação de educadores além de prestar colaboração, Sérgio Haddad vem nos falar de Ação Educativa, uma nova Organização Não-Governamental (ONG) na área de educação.

\section{BOLETIM BIBLIOGRÁFICO}

Videografia, neste número, deixou-se guiar pela Literatura. Nela você vai encontrar, por exemplo, o filme Menino de Engenho. A Bibliografia sobre telenovela continua, assim como a que se refere a Comunicação $e$ Educação. Escreva-nos você também falando sobre essa seção. Até agora temos recebido elogios. 